\title{
Effect of testosterone on serum immunoactive inhibin concentrations in intact and hypophysectomized male rats
}

\author{
Y. T. Sun, D. M. Robertson, G. Gonzales, G. P. Risbridger and \\ D. M. de Kretser
}

Department of Anatomy, Monash University, Clayton, Victoria 3168, Australia

\begin{abstract}
Summary. Intact and hypophysectomized rats were treated with graded doses of testosterone via subcutaneous Silastic implants over a 13-week period. Serum inhibin concentrations fell $50 \%(P<0.001)$ after 2 weeks of hypophysectomy, remaining suppressed at this level for 13 weeks. The administration of testosterone to hypophysectomized rats (serum testosterone values $2-12 \mathrm{ng} / \mathrm{ml}$; control values $5.5 \mathrm{ng} / \mathrm{ml}$ ) was without effect on serum inhibin values. In contrast, administration of testosterone to intact animals for 7 weeks resulted in an initial fall $(P<0.05)$ in inhibin levels to $50-70 \%$ of controls then increasing to reach control levels at higher doses. Serum FSH concentrations were similarly biphasic with increasing dose of testosterone and values for these two hormones were significantly correlated $(r=0.44, P<0.01)$. Segments of seminiferous tubules in culture from rats after various times of hypophysectomy showed a partly suppressed secretion of inhibin. The administration of testosterone did not modify inhibin production although inhibin production was sensitive to FSH.

It is concluded that (1) serum inhibin concentrations are partly suppressed after hypophysectomy and testosterone has no effect on serum inhibin values; and (2) the suppression of serum inhibin in intact rats treated with increasing doses of testosterone is attributable to the concomitant fall in serum FSH concentrations.
\end{abstract}

Keywords: inhibin; testosterone; hypophysectomy; rat

\section{Introduction}

Inhibin is a heterodimetric protein of gonadal original which preferentially suppresses FSH synthesis and secretion (McLachlan et al., 1988b; Ying, 1988; de Jong, 1988). Sertoli cells (Steinberger \& Steinberger, 1976; Verhoeven \& Franchimont, 1983; Ultee-van Gessel et al., 1986; Noguchi et al., 1987; Morris et al., 1988; Toebosch et al., 1988) or seminiferous tubules in culture (Gonzales et al., 1988 ) produce inhibin bio- and immunoactivity under basal conditions and its secretion is stimulated by FSH. Other factors (EGF, androstenedione; Morris et al., 1988) also affect inhibin secretion but their effects are limited. The effect of testosterone on inhibin secretion, with the exception of one report (Verhoeven \& Franchimont, 1983), is either non-detectable or inhibitory at very high (10-5 M) doses (Le Gac \& de Kretser, 1982; Ultee-van Gessel et al., 1986; Bicsak et al., 1987; Morris et al., 1988; Gonzales et al., 1988). However, two in-vivo studies suggest that LH/hCG and therefore possibly testosterone may be involved in inhibin synthesis in vivo. Administration of hCG to adult male rats results in a dramatic 7 -fold increase in serum inhibin (Drummond et al., 1989). This increase is inhibited if the Leydig cells are initially destroyed by the cytotoxic drug, ethane dimethane sulphonate, suggesting that a Leydig cell product was responsible. The failure to observe a direct relationship between serum inhibin and testosterone concentrations in this study suggests that testosterone was not the mediator. The administration of $\mathrm{LH}$ to men in whom $\mathrm{LH}$ and FSH concentrations were suppressed by androgen treatment resulted in an increase in serum inhibin 
values, presumably through the increased production of a Leydig cell product, i.e. testosterone. FSH also increased inhibin levels while the co-administration of LH and FSH led to even higher values (McLachlan et al., 1988a). Studies to date, however, have not examined the in-vivo effects of testosterone on serum inhibin.

The aim of this study was to examine the effects of hypophysectomy on inhibin secretion and to determine the effects of administration of testosterone to intact and hypophysectomized rats on serum inhibin concentrations.

\section{Materials and Methods}

Adult (85-90-day) Sprague-Dawley rats were obtained from the Monash Central Animal House.

\section{Hypophysectomy and testosterone treatment}

Animals, hypophysectomized using the parapharyngeal approach (Waynforth, 1980), were kept at $27^{\circ} \mathrm{C}$ and allowed free access to water and $5 \%$ glucose $/ 0.9 \%$ sodium chloride. The evaluation of complete hypophysectomy was established from the absence of any pituitary tissue in the sella turcica at the completion of the experiment and the corresponding non-detectable concentrations of serum FSH and LH.

Testosterone implants were prepared from polydimethylsiloxane tubing $(3.18 \mathrm{~mm}$ o.d. $\times 1.98 \mathrm{~mm}$ i.d.; Dow Corning, Midland, MI, USA) and medical adhesive silicone type A (Dow Corning). The testosterone capsules were implanted subcutaneously along the dorsal surface of rats under ether anaesthesia. The release rate of testosterone was $30 \mu \mathrm{g} / \mathrm{cm} /$ day.

\section{In-vivo experimental protocol}

Study 1 . Groups of hypophysectomized rats (5-8/group) and intact rats (5/group) as controls were examined after $1,2,3,4$ and 5 weeks.

Study 2. Groups of rats (4-10/group) were treated with testosterone by Silastic implants $(0,0 \cdot 5,1,1 \cdot 5,2,2 \cdot 5,3,5$, $6,7,8,9,10 \mathrm{~cm}$ ) for 2 weeks following hypophysectomy.

Study 3. Groups of rats (4-7/group) were treated with testosterone by Silastic implants $(0,3,10 \mathrm{~cm})$ for 13 weeks following hypophysectomy. Intact rats as controls ( 7 rats) were included.

Study 4. Groups of rats (7/group) were treated with testosterone by Silastic implants $(0,1 \cdot 5,2,2 \cdot 5,3,4,5,6,7,8,9$, $10,11,12,13,14,15,16 \mathrm{~cm})$ for 7 weeks.

Study 5. Groups of rats (7/group) were treated with testosterone by Silastic implants $(0,2,3,4,6,8,10,14 \mathrm{~cm})$ for 13 weeks.

Following decapitation, peripheral blood was collected and stored overnight at $4^{\circ} \mathrm{C}$. The serum obtained after centrifugation at $1000 \mathrm{~g}$ for $15 \mathrm{~min}$ was stored at $-20^{\circ} \mathrm{C}$. Testicular cytosols were prepared according to the method of Au et al. (1985).

\section{Seminiferous tubule cultures}

Testes from rats (6/group) $0,2,4,6$ and 8 days and 2,3,4 and 5 weeks after hypophysectomy were placed in a Petri dish containing Dulbecco's phosphate buffer pH 7.4 (DPB, CSL, Melbourne, Australia), the seminiferous tubules were dissected free and 5-cm segments cultured as previously described (Gonzales et al., 1988). The cultures were maintained for 4 days with a medium change on Day 2. In some experiments ovine FSH $(500 \mathrm{ng} / \mathrm{ml}$; NIADDK-S17, $\mathrm{NIH}$, Bethesda, MD, USA), testosterone $(100 \mathrm{ng} / \mathrm{ml})$ or both were added to the culture medium. The media from Days 2 and 4 of culture were collected separately and stored frozen.

\section{Assays}

Serum inhibin and testicular inhibin content were determined by a heterologous radioimmunoassay as previously described (Robertson et al., 1988) using an antiserum raised to purified bovine inhibin of $M_{\mathrm{r}} 31000$ and bovine inhibin of $M_{\mathrm{r}} 31000$ as tracer. A rat ovarian extract (ROVE-A) calibrated in terms of an in-house and in-vitro bioassay standard was used as standard (Robertson et al., 1988). The relative potency of this in-vitro bioassay standard in the in-vitro bioassay (Scott et al., 1980) in terms of the WHO porcine inhibin reference preparation (86/690) is equivalent to $25.9 \pm 0.80$ units $86 / 690$ per unit ROVE-A standard (Robertson et al., 1988). The between- and within- 
assay variations are $4.0 \%$ and $<10 \%$ respectively. Inhibin subunits obtained following reductive alkylation, TGF $\beta$ and Müllerian inhibitory substance showed $<0 \cdot 5 \%$ cross-reaction in the assay.

Serum FSH and LH concentrations were determined by radioimmunoassay. The FSH radioimmunoassay utilized iodinated rat FSH (NIADDK rFSH-15) as tracer, rat FSH antiserum (NIADDK anti-rFSH-S11) and rFSH-RP2 as standard. The within- and between-assay variations were $5 \cdot 2 \%$ and $8 \cdot 7 \%$ respectively. The sensitivity of the assay was $1.9 \mathrm{ng} / \mathrm{ml}$. Serum FSH concentrations from long-term hypophysectomized rats were $<1.9 \mathrm{ng} / \mathrm{ml}$. The LH radioimmunoassay utilized iodinated rat LH (NIADDK rLH-17) as tracer, rat LH antiserum (NIADDK anti-rLH S9) and rLH-RP2 as standard. The within- and between-assay variations were $6.9 \%$ and $9.7 \%$ respectively. The sensitivity of the assay was $0 \cdot 16 \mathrm{ng} / \mathrm{ml}$. Serum LH concentrations from long-term hypophysectomized rats were $<0 \cdot 16 \mathrm{ng} / \mathrm{ml}$.

Serum testosterone concentrations were determined by radioimmunoassay following an ether extraction procedure as previously described (Risbridger et al., 1981). The within- and between-assay variations were $7.3 \%$ and $9 \cdot 4 \%$ respectively. The sensitivity of the assay was $0.2 \mathrm{ng} / \mathrm{ml}$.

\section{Statistics}

The results were analysed using a multiple comparison test (Peritz' test) for differences among group means (Harper, 1984).

\section{Results}

\section{Effect of testosterone on serum inhibin concentrations after hypophysectomy}

Following hypophysectomy, serum inhibin values had fallen significantly $(P<0.001)$ to $50 \%$ by 2 weeks and remained partly suppressed for $2-5$ weeks (Fig. 1) and 13 weeks $(P<0.05$, Fig. 2). Serum inhibin in hypophysectomized rats remained unchanged after the administration of testosterone by Silastic implants $(0-10 \mathrm{~cm})$ for 2 or 13 weeks (Fig. 2). The testicular content of inhibin was suppressed $(P<0.001)$ for $1-5$ weeks after hypophysectomy (Fig. 1) and these values remained unchanged after testosterone administration for 2 weeks (Fig. 2b). The corresponding serum testosterone values increased linearly in proportion with implant length ranging from 20 to $200 \%$ of control levels (Fig. 2).
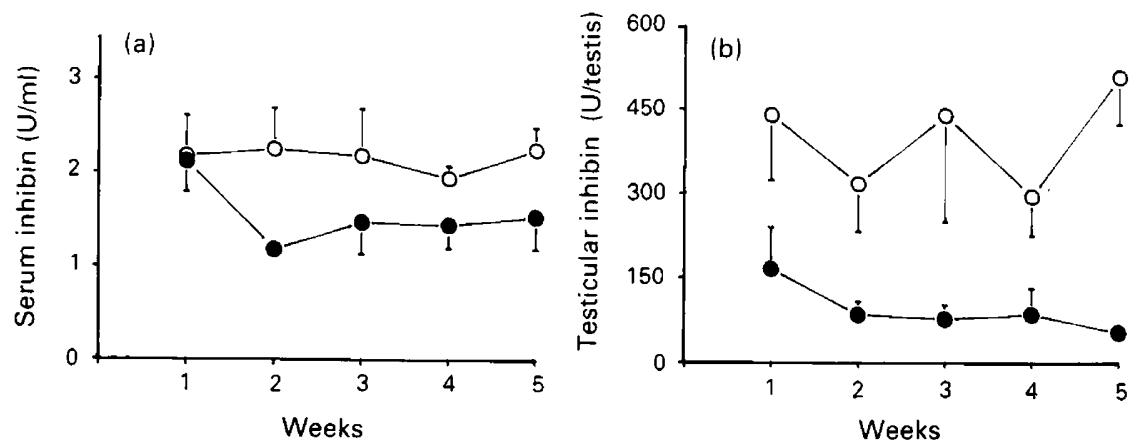

Fig. 1. Serum inhibin concentration and testicular inhibin content in control rats $(O)$ and rats 1-5 weeks after hypophysectomy $(\odot)$. Values are mean \pm s.d. with 5-8 rats/group.

\section{Effect of testosterone on serum inhibin concentrations in intact rats}

The administration of testosterone by Silastic implants $\left(0-16 \mathrm{~cm}\right.$, designated as groups $\mathrm{T}_{0.5-16}$ to intact rats for 7 weeks resulted in a significant fall $(P<0.05)$ in serum inhibin in the $\mathrm{T}_{3-6}$ group, returning to control levels in the $T_{10-16}$ group's. The corresponding serum FSH values decreased $(P<0.05)$ in the $\mathrm{T}_{1.5}$ group to reach a minimum (50\% of controls) in the $\mathrm{T}_{4}$ group, increasing 

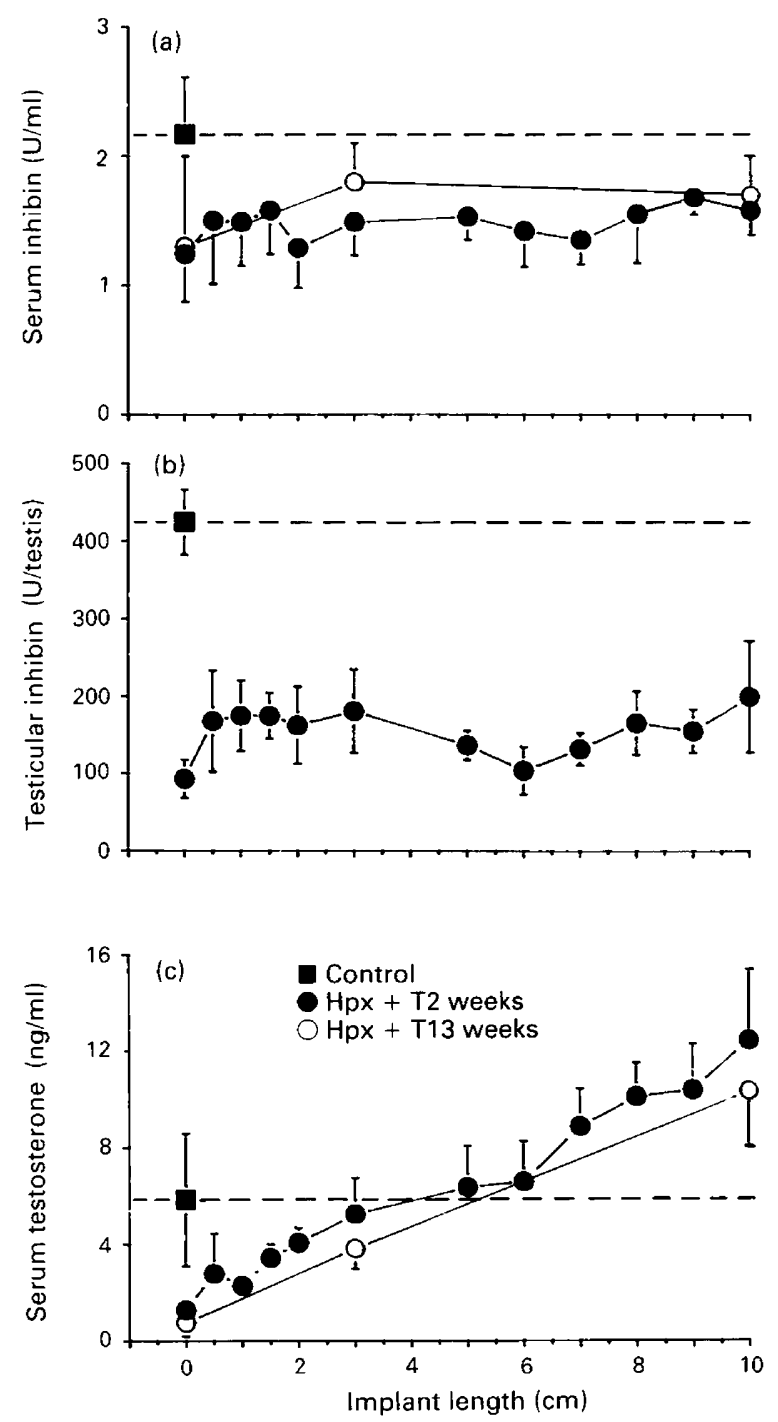

Fig. 2. Serum inhibin and testosterone concentrations and testicular inhibin content in hypophysectomized (Hpx) rats treated with testosterone by Silastic implants for 2 and 13 weeks. Values are mean \pm s.d. for 4-10 rats/group.

to reach $75 \%$ of control values in the $\mathbf{T}_{7}$ group and remaining unchanged in groups at the higher dose levels (Fig. 3).

After 13 weeks, serum inhibin concentrations decreased $(P<0.05)$ in the $\mathrm{T}_{3}$ group and reached $70 \%$ of control values in the $\mathrm{T}_{8}$ group. Serum FSH values fell $(P<0.05)$ in the $\mathrm{T}_{3}$ group $(60 \%$ of control), remaining partly suppressed at higher doses, unlike the data obtained at 7 weeks (Fig. 3). Serum testosterone values increased linearly in proportion with implant length of $8-16 \mathrm{~cm}$. At lower doses $(<6 \mathrm{~cm})$ serum testosterone levels were not different from controls. Serum LH concentrations were suppressed to values $30 \%$ of control in the $T_{0.5-3}$ groups and to undetectable values in the $\mathbf{T}_{4-16}$ groups (data not shown).

Regression analysis of serum inhibin vs serum FSH (Fig. 3) showed a significant correlation after 7 weeks $(r=0.44, P<0.05)$ and 13 weeks $(r=0.57, P<0.05)$. 
7 Weeks

13 Weeks
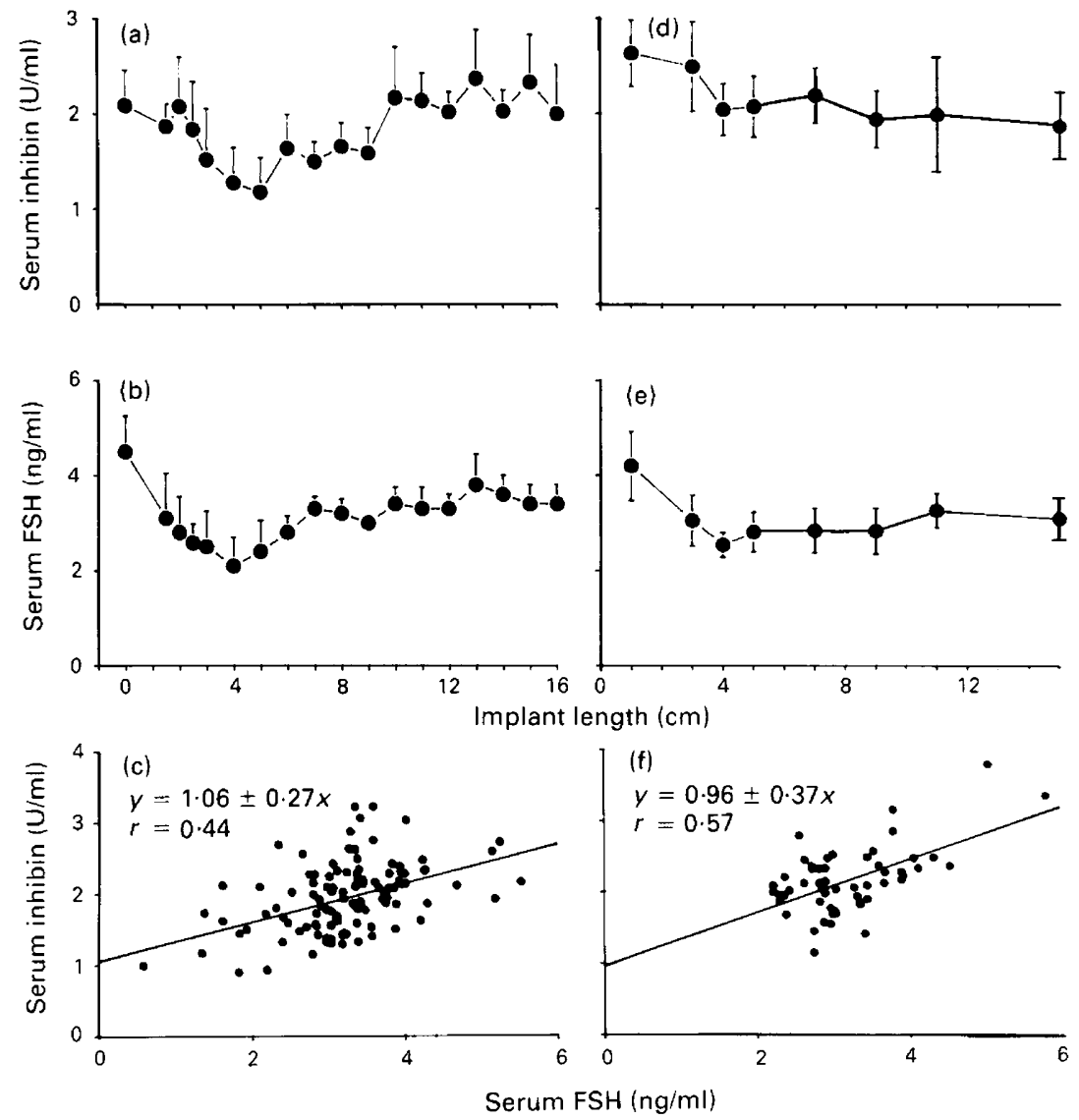

Fig. 3. Serum inhibin and FSH concentrations in rats treated with testosterone by Silastic implants for 7 and 13 weeks. Values are mean \pm s.d. with 7 rats/group.

In-vitro production of inhibin by seminiferous tubule segments obtained from rats at various times after hypophysectomy

Seminiferous tubules obtained from rats 2-35 days after hypophysectomy produced in 4-day cultures significantly $(P<0.05)$ less inhibin compared to intact controls (Fig. 4). Testosterone administration had no effect while the addition of FSH $(500 \mathrm{ng} / \mathrm{ml})$ led to a significant increase in inhibin production at all stages except Day 4 after hypophysectomy. However, the magnitude of the response varied, decreasing to a nadir at Day 4 and increasing thereafter to reach a plateau between Days 14 and 35 . The combined administration of FSH and testosterone $(100 \mathrm{ng} / \mathrm{ml}) \mathrm{did}$ not result in any further increase (Fig. 4).

\section{Discussion}

The results of this study show that serum inhibin concentrations are not totally suppressed following hypophysectomy even after extended periods, suggesting that either hormones of non-pituitary origin are involved or that Sertoli cells are able to produce inhibin constitutively. The latter possibility is the more likely as it has been shown that Sertoli cells (Le Gac \& de Kretser, 1982; Ultee-van Gessel et al., 1986) and seminiferous tubules (Gonzales et al., 1988) in culture in the 

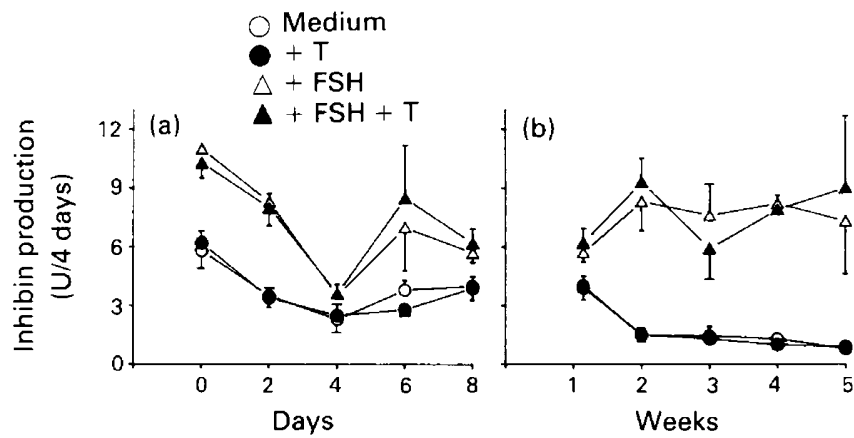

Fig. 4. Inhibin production by seminiferous tubules cultured for 4 days isolated from rats hypophysectomized for 0-8 days (a) and 1-5 weeks (b). Values are mean \pm s.d. with cultures from 6 rats/group.

absence of serum or stimulants are able to produce sustaining levels of inhibin for 2-7 weeks. Although the serum inhibin concentrations were partly suppressed, the corresponding testicular content of inhibin showed a dramatic fall to reach levels $20-30 \%$ of normal. The basis for this differential decrease in testicular inhibin values is unclear although a change in the bidirectional release of inhibin from the testis (Maddocks \& Sharpe, 1989) or a decrease in testicular inhibin stores with withdrawal of FSH are likely possibilities.

The in-vivo administration of testosterone to hypophysectomized rats over an extended period is without effect on serum inhibin concentrations, as previously reported for testicular bioactive inhibin values (Au et al., 1985). The resulting testosterone concentrations, while supraphysiological at the higher doses as reflected by hypertrophy of the prostate (data not shown), are low intratesticularly (Sharpe et al., 1988) and it is possible that considerably higher levels of testosterone approaching those found intratesticularly are required to produce an effect. However, the in-vitro culture of segments of seminiferous tubules from hypophysectomized rats at testosterone concentrations $(100 \mathrm{ng} / \mathrm{ml})$ similar to those found in rat interstitial fluid (Turner et al., 1984; Sharpe et al., 1988) does not modify inhibin production, in keeping with earlier findings with Sertoli cell (Bicsak et al., 1987; Toebosch et al., 1988; Morris et al., 1988) and seminiferous tubule (Gonzales et al., 1988) cultures. In contrast, the in-vivo administration of testosterone to intact animals results in a dose-related fall then rise (after 7 but not 13 weeks) of serum inhibin levels. A similar biphasic pattern is observed with serum FSH concentrations which are significantly positively correlated with the corresponding inhibin values. The rise in FSH levels at high testosterone concentrations has been previously reported (Rea et al., 1986) and attributed to the direct stimulatory effect of testosterone on the pituitary secretion of FSH. Regression analysis of serum inhibin and FSH at either 7 or 13 weeks results in similar slope and intercept values. The intercept value on the $y$ (serum inhibin) axis (Fig. 3) is similar to that found after hypophysectomy (Figs $1 \& 2$ ). If this inhibin value $(\sim 1 \mathrm{unit} / \mathrm{ml})$ is taken as a 'non-stimulated' level, the positive correlation between serum FSH and inhibin concentrations would suggest that serum inhibin concentrations are partly $(\sim 50 \%)$ under FSH control and partly under local control mechanisms.

In conclusion, the partial maintenance of inhibin secretion both in vivo and by seminiferous tubules in vitro following hypophysectomy suggests that inhibin production is partly dependent on pituitary stimulation and partly on local testicular mechanisms. Testosterone administration is without effect on serum inhibin concentrations after hypophysectomy while, in the intact rat, the change in inhibin values is attributed to the parallel testosterone-induced changes in serum FSH concentrations.

The rat gonadotrophin radioimmunoassay kits were gifts from the NIADDK, Bethesda, MD, USA. This study was funded by a programme grant from the NH and MRC of Australia. Y.T.S. 
and G.F.G. are recipients of grants provided by the World Health Organization and Monash University.

\section{References}

Au, C.L., Robertson, D.M. \& de Kretser, D.M. (1985) Effects of hypophysectomy and subsequent FSH and testosterone treatment on inhibin production by adult rat testes. J. Endocr. 105, 1-6.

Bicsak, T.A., Vale, W., Vaughan, J., Tucker, E.M., Cappel, S. \& Hsueh, A.J.W. (1987) Hormonal regulation of inhibin production by cultured Sertoli cells. Molec. cell. Endocr. 49, 211-217.

de Jong, F.H. (1986) Inhibin. Phys. Review 68, 555-607.

Drummond, A.E., Risbridger, G.P. \& de Kretser, D.M. (1989) The involvement of Leydig cells in the regulation of inhibin secretion by the testis. Endocrinology (in press).

Gonzales, G.F., Risbridger, G.P. \& de Kretser, D.M. (1988) In vitro synthesis and release of inhibin in response to FSH stimulation by isolated segments of seminiferous tubules from normal adult male rats. Molec. cell. Endocr. 59, 179-185.

Harper, J.F. (1984) Peritz' F test: basic program of a robust multiple comparison test for statistical analysis of all differences among group means. Comput. Biol. Med. 14, 437-445.

Le Gac, F. \& de Kretser, D.M. (1982) Inhibin production by Sertoli cell cultures. Molec. cell. Endocr. 28, 487-498.

Maddocks, S. \& Sharpe, R.M. (1989) The route of secretion of inhibin from the rat testis. J. Endocr. 120, R5-R8.

McLachlan, R.I., Matsumoto, A.M., Burger, H.G., de Kretser, D.M. \& Bremner, W.J. (1988a) Relative roles of FSH and LH in the control of inhibin secretion in normal men. J. clin. Invest. 88, 880-884.

McLachlan, R.I., Robertson, D.M., de Kretser, D.M. \& Burger, H.G. (1988b) Advances in the physiology of inhibin and inhibin-related peptides. Clin. Endocr. 29, 77-144.

Morris, P.L., Vale, W.W., Cappel, M.S. \& Bardin, C.W. (1988) Inhibin production by primary Sertoli cellenriched cultures: regulation by FSH, androgens and EGF. Endocrinology 122, 717-725.

Noguchi, K., Keeping, H.S., Winters, S.J., Saito, H., Oshima, H. \& Troen, P. (1987) Identification of inhibin secreted by Cynomolgus monkey Sertoli cell cultures. J. clin. Endocr. Metab. 64, 783-787.

Rea, M.A., Marshall, G.R., Weinbauer, G.F. \& Nieschlag, E. (1986) Testosterone maintains pituitary and serum FSH and spermatogenesis in gonadotrophin-releasing hormone antagonist-suppressed rats. J. Endocr. 108, $10 !-107$
Risbridger, G.P., Kerr, J.B., Peake, R.A. \& de Kretser, D.M. (1981) An assessment of Leydig cell function after bilateral or unilateral efferent duct ligation: further evidence for local control of Leydig cell function. Endocrinology 109, 1234-1241.

Robertson, D.M., Hayward, S., Irby, D., Jacobsen, J., Clarke, L., McLachlan, R.I. \& de Kretser, D.M. (1988) Radioimmunoassay of rat serum inhibin: changes after PMSG stimulation and gonadectomy. Molec. cell. Endocr. 58, 1-8.

Scott, R.S., Burger, H.G. \& Quigg, H. (1980) A simple and rapid in vitro bioassay for inhibin. Endocrinology 107, 1536-1542.

Sharpe, R.M, Donachie, K. \& Cooper, I. (1988) Reevaluation of the intratesticular level of testosterone required for quantitative maintenance of spermatogenesis in the rat. J. Endocr. 117, 19-26.

Steinberger, A. \& Steinberger, E. (1976) Secretion of an FSH-inhibiting factor by cultured Sertoli cells. Endocrinology 99, 918-921.

Toebosch, A.M.W., Robertson, D.M., Trapman, J., Klaassen, P., de Paus, R.A., de Jong, F.H. \& Grootegoed, J.A. (1988) Effects of FSH and IGF-I on immature Sertoli cells: inhibin $\alpha$ - and $\beta$-subunit mRNA levels and inhibin secretion. Molec. cell. Endocr. 55, 101-105.

Turner, T.T., Jones, C.E., Howards, S.S., Ewing, L.L., Zegeye, B. \& Gunsalus, G.L. (1984) On the androgen microenvironment of maturing spermatozoa. Endocrinology 115, 1925-1932.

Ultee-van Gessel, A.M., Leemborg, F.G., de Jong, F.H. \& van der Molen, H.J. (1986) In vitro secretion of inhibin-like activity by Sertoli cells from normal and prenatally irradiated immature rats. J. Endocr. 109, $411-418$.

Verhoeven, G. \& Franchimont, P. (1983) Regulation of inhibin secretion by Sertoli cell-enriched cultures. Acta endocr., Copenh. 102, 136-143.

Waynforth, H.B. (1980) Specific surgical operations. In Experimental and Surgical Technique in the Rat, $\mathbf{p}$. 143. Academic Press, London.

Ying, S-Y. (1988) Inhibins, activins and follistatins: gonadal proteins modulating the secretion of folliclestimulating hormone. Endocr. Rev. 9, 267-293.

Received 14 April 1989 